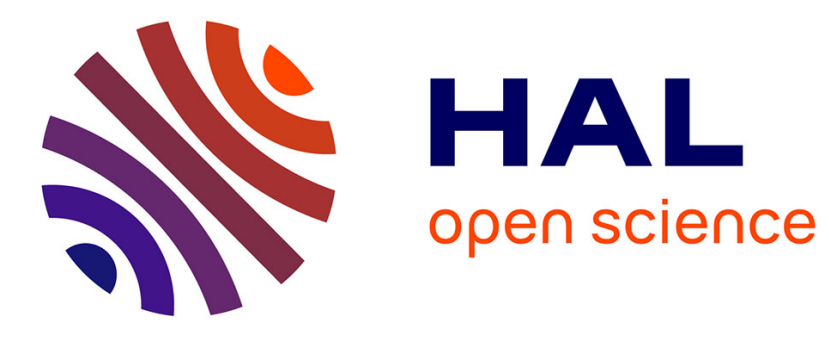

\title{
High-performance liquid chromatographic method for the determination of sorafenib in human serum and peritoneal fluid
}

Werner J. Heinz, Kathrin Kahle, Annegret Helle-Beyersdorf, Diana Schirmer, Ulrike Lenker, Daniela Keller, Peter Langmann, Hartwig Klinker

\section{To cite this version:}

Werner J. Heinz, Kathrin Kahle, Annegret Helle-Beyersdorf, Diana Schirmer, Ulrike Lenker, et al. High-performance liquid chromatographic method for the determination of sorafenib in human serum and peritoneal fluid. Cancer Chemotherapy and Pharmacology, 2010, 68 (1), pp.239-245. 10.1007/s00280-010-1474-y . hal-00629967

\section{HAL Id: hal-00629967 https://hal.science/hal-00629967}

Submitted on 7 Oct 2011

HAL is a multi-disciplinary open access archive for the deposit and dissemination of scientific research documents, whether they are published or not. The documents may come from teaching and research institutions in France or abroad, or from public or private research centers.
L'archive ouverte pluridisciplinaire HAL, est destinée au dépôt et à la diffusion de documents scientifiques de niveau recherche, publiés ou non, émanant des établissements d'enseignement et de recherche français ou étrangers, des laboratoires publics ou privés. 
High-performance liquid chromatographic method for the determination of sorafenib in human serum and peritoneal fluid

Werner J. Heinz*, Kathrin Kahle, Annegret Helle-Beyersdorf, Diana Schirmer, Ulrike Lenker, Daniela Keller, Peter Langmann, Hartwig Klinker

University of Würzburg Medical Centre, Department of Internal Medicine II, Oberdürrbacher Str. 6, 97080 Würzburg, Germany.

Running title: Determination of Sorafenib concentrations in serum peritoneal fluid

*Address correspondence to: Werner J. Heinz; Department of Internal Medicine II, University of Würzburg Medical Centre, Oberdürrbacher Str. 6, 97080 Wuerzburg, Germany. Tel.: +49931201 40044. Fax: + 49931201640044 .

E-mail: Heinz_W@klinik.uni-wuerzburg.de

Electronic Word count: 4518

Number of figures: 3

Number of tables: 3

Disclosures: none.

This work was supported by the German Federal Ministry of Economics und Technology (BMWi) and the European Social Fund (ESF), Project no. 03EGSBY044. 


\section{Abstract}

Purpose: Sorafenib is recommended for therapy of advanced hepatocellular carcinoma and renal cell carcinoma. Preclinical data indicate a relation between dose and antitumor efficacy. In clinical trials adverse events improve after dose reduction suggesting a dose-dependent toxicity. Given dose has a direct impact on the drug serum concentration, but the latter also can be influenced by multiple factors including interaction and metabolization. To enable the investigation of concentration related effects, an easy and sensitive assay for sorafenib drug monitoring is essential.

Methods: A high performance liquid chromatography (HPLC) analysis involving an extraction with diethyl ether followed by separation on a Pinnacle ${ }^{\mathrm{TM}}$ DB C18 column and quantitation by UV absorbance at $260 \mathrm{~nm}$ was established. Sorafenib concentrations in samples of serum and peritoneal fluid have been determined.

Results: The assay was validated for serum samples and is linear over the concentration range of 100 to $5000 \mathrm{ng} / \mathrm{mL}$ with a determination coefficient of $>0.999$. The limit of detection is $0.25 \mathrm{ng} / \mathrm{mL}$. The intra- and inter-day coefficients of variation were below 3.03\%. Sorafenib recovery in spiked probes of peritoneal fluid was above $85 \%$. Sorafenib concentrations in 44 serum samples and 14 probes of peritoneal fluid have been determined with a mean of 3328 and $1380 \mathrm{ng} / \mathrm{mL}$ respectively (standard deviation 2267 and $659 \mathrm{ng} / \mathrm{ml}$ ).

Conclusions: A sensitive and selective HPLC method for the determination of sorafenib in human serum was developed and also verified for peritoneal fluid. This method provides a useful tool for pharmacokinetic investigations as well as for therapeutic drug monitoring of sorafenib.

Keywords: Sorafenib; Hepatocellular carcinoma; HPLC; Validation; Serum concentrations; peritoneal fluid 


\section{INTRODUCTION}

Sorafenib, a potent competitive oral multikinase inhibitor is suppressing the activity of several cell surface receptor tyrosine kinases, like vascular endothelial growth factor receptor (VEGFR) and platelet-derived growth factor receptor and also intracellular members of the mitogen-activated protein kinase (MAPK) signal transduction pathway [1]. Including downregulation of antiapoptotic protein this pluripotent inhibition has an effect on tumour cell proliferation, survival and tumour angiogenesis. These mechanisms have successfully been applied in the treatment of cancer in several preclinical and clinical trials [2, 3]. Today sorafenib is recommended for treatment of renal cell carcinoma [4] and currently the antitumor activity is tested for therapy of several other malignoma.

Even more convincing sorafenib has shown to prolong survival of patients with hepatocellular carcinoma (HCC) [5] and is recommended by the US National Comprehensive Cancer Network guideline for advanced HCC in Child-Pugh A or B patients [6]. If unresectable this disease is characterized by a median overall survival below one year and extrahepatic metastases, including peritoneal dissemination $[7,8]$. The latter causes ascites and further complications, which can severely hamper patient's quality of life.

Several lines of evidence suggest a dose dependent efficacy and tolerability of sorafenib. So, in vitro induction of apoptosis and inhibition of cell proliferation with sorafenib in HCC cells lines have shown to be dose dependent. A dose-related antitumour activity in a murine xenograft model of PLC/PRF/5 human HCC could be demonstrated [9]. In addition, in 26\% of sorafenib recipients in a phase 3 trial dose has been reduced in order to terminate or improve adverse events [5]. Finally, pooled data suggest a relation between dose and toxicity as well as dose and efficacy [10]. 
Sorafenib is rapidly absorbed after oral administration and undergoes enterohepatic circulation; its elimination half-life is about 25 - 48 hours. Metabolization of sorafenib mainly occurs in the liver via oxidation by CYP3A4 ( $N$-oxide) and via glucuronidation by UGT1A9. Pharmacokinetic interactions of sorafenib with substrates of CYP2B6, CYP2C8, CYP 2C9, UGT1A1, UGT1A9 and $p$-Gp, e. g. irinotecan or doxorubicin, can not be excluded (2-4). The incidence of HCC is associated with liver cirrhosis and impaired liver function, which can significantly alter the described way of drug elimination.

In order to manage possible drug interactions, to ensure an effective exposure to sorafenib and to balance interindividual pharmacokinetic variability, therapeutic drug monitoring might be a useful tool. Knowledge of sorafenib concentration in peritoneal fluid might be helpful to adress further questions, as to prove the potency of clinical response in established peritoneal carcinomatosis or to evaluate a possible protection of intra-abdominal dissemination.

Here we describe a valid, rapid and sensitive HPLC-based method for the determination of sorafenib in human serum and peritoneal fluid.

\section{MATERIALS AND METHODS}

\section{Chemicals and reagents}

Sorafenib-Tosylate was kindly provided by Bayer Health Care AG (Leverkusen, Germany). The internal standard (IS) itraconazole as well as bovine serum albumin (BSA) powder (Albumin, bovine serum, fraction V, minimum 96\%) were obtained from Sigma-Aldrich (Steinheim, Germany). Acetonitrile, diethyl ether, ethanol, potassium dihydrogen phosphate, anhydrous sodium carbonate, sodium hydrogencarbonate and demineralised distilled water were purchased from Merck (Darmstadt, Germany). All chemicals and solvents were of analytical or HPLC grade. 


\section{Instrumentation}

Chromatographic analyses were carried out on a Beckman-Coulter Gold HPLC system (Krefeld, Germany) equipped with a 126 solvent delivery module, a 168 UV-VIS photodiode array detector, and a 508 autosampler. Data acquisition and analysis were performed with the Beckman System 32 Karat software. A Pinnacle ${ }^{\mathrm{TM}}$ DB C18 column, $150 \times 2.1 \mathrm{~mm}$, with 5 $\mu \mathrm{m}$ particle size (Restek, GmbH, Bad Homburg, Germany) protected by a C18 guard column ( $4 \times 2 \mathrm{~mm}$; Phenomenex, Aschaffenburg, Germany) was used. The mobile phase consisted of potassium dihydrogen phosphate $(20 \mathrm{mM})$ and acetonitrile $(35: 65, \mathrm{v} / \mathrm{v})(\mathrm{pH} 6.3)$. The flow rate was set at $0.2 \mathrm{~mL} / \mathrm{min}$. Sorafenib and IS were determined at $260 \mathrm{~nm}$. A peak controlled spectrum recording was selected with a range of $190-300 \mathrm{~nm}$.

\section{Preparation of stock solutions, working solutions and quality control samples}

Stock solution of sorafenib $(2.5 \mathrm{mg} / 100 \mathrm{~mL})$ was prepared in ethanol and diluted for the preparation of working solutions at concentrations of 50, 100, 250, 500, 1000, 2500, 5000 and $10000 \mathrm{ng} / \mathrm{mL}$. The IS (itraconazole) working solution was prepared in methanol at a concentration of $5.0 \mathrm{mg} / 100 \mathrm{~mL}$. Each solution was stored at $-20{ }^{\circ} \mathrm{C}$ and was stable for at least three months.

For the preparation of serum standard samples, BSA solutions $(5 \%, \mathrm{w} / \mathrm{v})$ were spiked with sorafenib and IS (10000 ng/mL) to obtain the above mentioned calibration and QC concentrations.

\section{Sample preparation}

A $250 \mu 1$ aliquot of BSA standard, serum samples or peritoneal fluid was mixed with $500 \mu 1$ of sodium carbonate buffer $(0.1 \mathrm{M}, \mathrm{pH} 9.4)$ in a $10 \mathrm{~mL}$ glass tube. The IS (50 $\mu \mathrm{l})$ was added and the solutions were briefly vortexed. Samples were extracted twice with $3 \mathrm{~mL}$ of diethyl ether for $5 \mathrm{~min}$, followed by centrifugation at $4200 \times g(5 \mathrm{~min})$. The organic layers were 
transferred into a glass tube and evaporated to dryness at $37{ }^{\circ} \mathrm{C}$ under a gentle stream of nitrogen. The dried residue was dissolved with $200 \mu \mathrm{l}$ of $20 \mathrm{mM}$ potassium dihydrogen phosphate in acetonitrile $(1: 1, \mathrm{v} / \mathrm{v})$ and a $25 \mu \mathrm{l}$ volume was injected into the HPLC system.

\section{Validation}

\section{Linearity}

Complete calibration curves were analysed in duplicate on three separate days. A linear regression with a weighting factor of $1 /$ (peak height ratio) $^{2}$ was used to plot the peak height ratio (height of sorafenib/height of IS) versus the corresponding sorafenib concentration. Slopes, $y$-intercepts, and correlation coefficients $\left(r^{2}\right)$ were calculated.

\section{Accuracy and precision}

Intra-day accuracy and precision of the method were determined by measuring 12 replicates of each QC concentration on the same day. This procedure was repeated on 12 different days to test the inter-day accuracy and precision. Accuracy was calculated as the relative error of the nominal concentration. Precision was expressed as the coefficient of variation and obtained by analysis of variance (ANOVA) for each test concentration using the analytical run as the grouping variable.

\section{Sensitivity}

The limit of detection (LOD) was defined as the lowest detectable concentration level resulting in a signal-to-noise ratio of three [11]. For the lower limit of quantitation (LLQ), accuracy (deviation from nominal concentration) and precision (relative standard deviation) should not exceed 20\% [12]. The upper limit of quantitation (ULQ) was arbitrarily set at 20000 ng/mL. 


\section{Recovery}

The recovery of sorafenib and IS in serum were performed in quadruplicate by comparing the analytical results for extracted QC samples with unextracted standards presenting 100\% recovery. Samples of peritoneal fluid from five patients without sorafenib medication were spiked with increasing concentrations of 100, 250, 500, 1000 and $5000 \mathrm{ng} / \mathrm{ml}$ sorafenib. Recovery in spiked ascites was determined in parallel with the calibration of serum samples.

\section{Specificity and selectivity}

The specificity of the method was indicated by the absence of any endogenous interfering peaks. For testing method selectivity, drug-free BSA solutions were spiked with therapeutic concentrations of diazepam, fentanyl, furosemide, metamizole sodium, pantoprazole, propanolol, spironolactone, tilidine, tramadole, and torasemide.

\section{Stability}

Stability studies of sorafenib in spiked BSA solutions were performed with QC samples. Four series of each QC concentration were stored for 30 days at $-20{ }^{\circ} \mathrm{C}, 7$ days at $-20{ }^{\circ} \mathrm{C}$ including 3 freeze-thaw cycles, 7 days at $4{ }^{\circ} \mathrm{C}, 24 \mathrm{~h}$ at room temperature and $60 \mathrm{~min}$ at $56{ }^{\circ} \mathrm{C}$. Longterm stability was determined following three months of storage at $-20{ }^{\circ} \mathrm{C}$. After each storage period the concentration of sorafenib was analysed and compared to freshly prepared QC samples.

\section{Analysis of patient samples}

Blood samples from patients treated with sorafenib for the therapy of HCC were taken after ingestion of $400 \mathrm{mg}$ sorafenib twice every day (BID). Serum samples were obtained by a 
standardised procedure. Samples of peritoneal fluid were collected in case of paracenteses. Simultaneously cell count, lactate dehydrogenase, cholesterin, triglycerid, glucose- and protein concentrations were determined. All samples were separated by centrifugation at 4200 $\times g$ for $10 \mathrm{~min}$ at $20^{\circ} \mathrm{C}$ and immediately stored at $-20{ }^{\circ} \mathrm{C}$ until further analysis. Determination of sorafenib concentrations in patients' peritoneal fluid were performed in the same assay and with the calibration of serum samples.

\section{Calculation and data analysis}

All statistical calculations were performed with Statistical Product and Service Solutions (SPSS) for Windows, version 17.0 (SPSS, Chicago, Illinois, USA). T-tests of mean concentrations and correlations were considered statistically significant at $p$-values $\leq 0.05$.

\section{RESULTS}

\section{Sample preparation, chromatography and detection}

Representative HPLC-chromatograms of a drug-free BSA sample (blank) and a BSA sample spiked with $2500 \mathrm{ng} / \mathrm{mL}$ sorafenib and the IS are shown in Figure 1. Retention times for sorafenib and IS were 4.65 and $6.48 \mathrm{~min}$. No interfering endogenous peaks were detectable in the blank sample. In this assay the chromatographic run-time was 10 min.

\section{Linearity and recovery}

The linearity of the method was evaluated over a concentration range of $100-5000 \mathrm{ng} / \mathrm{mL}$. Using the ratios of observed peak heights for sorafenib and IS in six spiked BSA samples analysed in duplicate, the calibration curves showed a correlation coefficient $\left(r^{2}\right)$ of $>0.999$ with a mean slope of $3806.70 \pm 109.62$ and a mean $y$-intercept of $23.260 \pm 3.662$. Highest 
recovery values with $97.66 \pm 1.67 \%$ for sorafenib and $88.29 \pm 2.04 \%$ for IS were achieved at $\mathrm{pH} 9.4$.

\section{Accuracy and precision}

Intra- and inter-day accuracy and precision data of QC samples are shown in Table 1. Intraday accuracy, expressed as the relative error (RE; in percent) ranged from 0.22 to $0.77 \%$. Intra-day precision, expressed as the coefficient of variation $(\mathrm{CV}$; in percent) was 0.60 to $3.03 \%$. The inter-day accuracy and precision were less than -3.55 and $2.62 \%$, respectively.

\section{Sensitivity and specificity}

The LOD of sorafenib in plasma was determined at $0.25 \mathrm{ng} / \mathrm{mL}$, and LLQ was established at a concentration of $50 \mathrm{ng} / \mathrm{mL}$. ULQ was arbitrarily set at $20000 \mathrm{ng} / \mathrm{mL}$.

Serum samples from both patients treated with sorafenib and healthy individuals were devoid of interference near the retention times of sorafenib and IS under the used chromatographic conditions.

The analysis of spiked drug-free BSA samples diazepam, fentanyl, furosemide, metamizole sodium, pantoprazole, propanolol, spironolactone, tilidine, tramadole, or torasemide showed no interference neither with the extraction procedure nor with the analytical method.

\section{Stability}

Freeze-thaw stability of QC in spiked BSA samples was demonstrated after 7 days of storage at $-20{ }^{\circ} \mathrm{C}$ including three freeze-thaw cycles. Sorafenib was also stable after 30 days at $-20{ }^{\circ} \mathrm{C}$, 7 days at $4{ }^{\circ} \mathrm{C}, 24 \mathrm{~h}$ at room temperature, $60 \mathrm{~min}$ at $56{ }^{\circ} \mathrm{C}$ and after 3 month at $-20{ }^{\circ} \mathrm{C}$ (Table 2). RE and CV were less than $2.75 \%$ and $3.73 \%$, respectively. 


\section{Sorafenib in peritoneal fluid}

Clinical parameters of spiked peritoneal fluid are shown in table 3, representing a broad range of clinical conditions, as demonstrated by leukocyte count, glucose concentration and osmolarity. Peak heights in chromatography were not significantly different for samples of blank serum or peritoneal fluid, when spiked with either 100, 250, 500, 1000 or $5000 \mathrm{ng} / \mathrm{ml}$ sorafenib $(<10 \%$, data not shown). For recovery of sorafenib in spiked samples of ascites a maximum deviation of $14 \%$ in concentration has been determined and this has been most pronounced in samples with the highest concentrations. Mean concentrations have been within $10 \%$ of the expected value (Figure 2).

\section{Analysis of patient samples}

Fourtyfour serum samples were taken after ingestion of $400 \mathrm{mg}$ sorafenib BID. Determined sorafenib concentrations ranged from undetectable to $8833 \mathrm{ng} / \mathrm{mL}$, with a mean of 3747 $\mathrm{ng} / \mathrm{mL}$ and a of median $3881 \mathrm{ng} / \mathrm{mL}$. The standard deviation was calculated as $2267 \mathrm{ng} / \mathrm{ml}$. Only two concentrations were below $100 \mathrm{ng} / \mathrm{ml}$ and altogether 6 below $1000 \mathrm{ng} / \mathrm{ml}$. Most concentrations (28/44) were in the range of 1000 to $6000 \mathrm{ng} / \mathrm{ml}$, three, two and two concentrations were between 6000 to 7000,7000 to 8000 and 8000 to $9000 \mathrm{ng} / \mathrm{ml}$, respectively.

In fourteen samples of peritoneal fluid sorafenib concentrations had a much smaller range of 510 to $2757 \mathrm{ng} / \mathrm{ml}$, with a mean of $1380 \mathrm{ng} / \mathrm{ml}$, a median of $1235 \mathrm{ng} / \mathrm{mL}$ and a standard deviation of $659 \mathrm{ng} / \mathrm{ml}$. Half of the samples had a concentration between 1100 and 1900 $\mathrm{ng} / \mathrm{mL}$. Ascites and serum sorafenib mean concentrations were significantly different ( $\mathrm{p}$ $<0.01)$ and are illustrated in figure 3.

\section{DISCUSSION}


Here we established an easy and reproducible method for determination of sorafenib concentration in serum and peritoneal fluid. This assay facilitates a precious determination of sorafenib at least in the range of 50 to $20000 \mathrm{ng} / \mathrm{ml}$. No interference with other compounds was detected. Sorafenib concentrations were quantified in fourtyfour serum samples from patients treated with this tyrosine kinase inhibitor. In addition, relevant amounts of sorafenib were detected in fourteen probes of peritoneal fluid. The median of the later was below the concentrations in serum, but still in the range previously described in human plasma.

Only a few methods for quantification of sorafenib in human or mouse plasma by highperformance liquid chromatography-tandem mass spectrometry (HPLC-MS/MS) [13-15] were reported so far. Although HPLC-MS/MS techniques require only small sample volumes and minimal sample preparation they are expensive and not generally available. Up to now, only two HPLC-UV assays were published for the determination of sorafenib either in mouse serum [16] or in human plasma [17] using sample preparation by protein precipitation with acetonitrile in combination with liquid-liquid extraction. Avoiding this complex preparation, in the here described assay, a $250 \mu \mathrm{L}$ aliquot of human serum following liquid-liquid extraction with diethyl ether was used. Flow rate and the chromatographic run-time were reduced to $0.2 \mathrm{~mL} / \mathrm{min}$ and $10 \mathrm{~min}$, respectively, making this assay faster and more costeffective. Most important for our HPLC method we were able to demonstrate an improved sensitivity.

In addition, we tested the assay for determination of sorafenib concentration in peritoneal fluid. Here, recovery and precision of expected and determined concentration were satisfactory for clinical use over a spectrum of sorafenib concentrations, clearly broader than the concentrations recovered in patient plasma samples. As reflected by standard laboratory parameters including leukocyte count, used probes of peritoneal fluid represent a broad range of clinical conditions, including a spontaneous bacterial peritonitis. Therefore, the assay, 
which was introduced here, makes it easy to determine sorafenib concentration in blood and ascites. Furthermore both can be tested simultaneously.

Some data suggest a correlation between prescribed drug doses and clinical efficacy or adverse events [10]. In a dose escalation trial, drug related grade 3 adverse events were limited to the higher doses (400 and $800 \mathrm{mg}$ BID) but did not occur at doses of 100 or $200 \mathrm{mg}$ BID [18]. Also a dose-dependent relationship for certain adverse events was observed and due to an unacceptable incidence rate of dose limiting toxicity at $600 \mathrm{mg}$ BID in a phase I study $400 \mathrm{mg}$ BID was chosen for maximum tolerated dose [19].

Although dose triggers drug concentration, the latter is also influenced by several other factors, like drug interaction, impaired liver function, inhibited or induced metabolization and compliance. Especially in HCC patients an impaired liver function is common, but only very limited data on pharmacokinetics for Child-Pugh A or B patients exist from a phase I trial in 14 Japanese patients and 22 patients in a phase II trial [20, 21], but none for Child-Pugh C and effect on liver function including cytochrome p450 activity can be extremely heterogeneous in patients with the same stage of liver cirrhosis.

Up to now, only few data are published on sorafenib concentrations and mainly mean or median results of AUC and maximum concentrations are mentioned. This makes it difficult to investigate a correlation of effects, positive or negative, to drug concentration. So, in a phase I trial 9 subjects receiving $400 \mathrm{mg}$ sorafenib BID had a mean $\mathrm{C}_{\max }$ at day seven of $9.90 \mathrm{mg} / \mathrm{L}$ with a standard deviation of 1.52 and a range of $5.63-23.0 \mathrm{mg} / \mathrm{L}$ [19]. Maximum concentrations are more difficult to obtain in clinical practise compared to trough levels. Here we could show a broad range of individual sorafenib trough concentrations in serum samples. Intra- and interindividual differences as well as their impact on antitumor activity and drug safety have to be investigated in prospective trials. We also could demonstrate significant different sorafenib concentrations in peritoneal fluid. Drug concentration in this body 
compound might be influenced by additional determinants. These include but are not limited to cause of ascites (exsudative and transudative), volume and time of development. Nevertheless, observed sorafenib concentrations are within a restricted spectrum. A potential protective or therapeutic effect for peritoneal carcinosis still has to be evaluated.

The described assay might help to evaluate the impact of potential drug interactions, especially as studies for the use of sorafenib in combination with e.g. irinotecan, evorolimus or bortezomib for treatment of HCC have already started [22-24].

\section{CONCLUSIONS}

We have developed and validated a simple, selective and reliable analytical assay for the determination of sorafenib in human serum which can readily be used in a standard laboratory. The practicability of the assay is demonstrated by serum levels of 44 patient samples. In addition, we were able to show that the method is also qualified to quantify sorafenib concentrations in peritoneal fluid, and results of 14 samples are presented. To our knowledge for the first time, significant sorafenib concentrations within the range observed in plasma have been demonstrated in peritoneal fluid. So far, its clinical implications remain to be determined. In particular, serum showed a broad range of sorafenib concentrations. Further and prospective investigations are necessary and warranted for evaluation of concentration dependent effects.

The described assay can already be useful as a tool for therapeutic drug monitoring in order to optimise drug dosage on an individual basis. It can also be used for pharmacokinetic and pharmacodynamic studies of sorafenib. 


\section{Tables}

Table 1: Intra- and inter-day accuracy (RE; \%) and precision (CV; \%) for the determination of sorafenib in spiked serum samples by HPLC; ${ }^{a}$ observed concentrations as a mean of $12 \pm$ SD

\begin{tabular}{lccc}
\hline Nominal concentration $(\mathrm{ng} / \mathrm{mL})$ & Observed concentration ${ }^{\mathrm{a}}(\mathrm{ng} / \mathrm{mL})$ & $\mathrm{RE}(\%)$ & $\mathrm{CV}(\%)$ \\
\hline Intra-day $(\mathrm{n}=12)$ & & & \\
100 & $99.49 \pm 3.01$ & 0.51 & 3.03 \\
2500 & $2494.5 \pm 37.57$ & 0.22 & 0.60 \\
5000 & $4961.3 \pm 121.6$ & 0.77 & 2.45 \\
& & & \\
Inter-day $(\mathrm{n}=12)$ & & & \\
100 & $103.5 \pm 2.46$ & -3.54 & 2.38 \\
2500 & $2564.1 \pm 66.89$ & -2.57 & 2.61 \\
5000 & $5108.0 \pm 129.1$ & -2.16 & 2.53 \\
\hline
\end{tabular}


Table 2: Stability of three sorafenib concentrations in spiked $5 \%$ BSA solution, at different temperatures, storing conditions, and durations as listed in column 1; ${ }^{a}$ Mean of observed concentrations; $\mathrm{n}=4$;

\begin{tabular}{lccc}
\hline Nominal concentration $(\mathrm{ng} / \mathrm{mL})$ & 100 & 2500 & 5000 \\
\hline 30 days at $-20{ }^{\circ} \mathrm{C}$ & & & \\
Mean $(\mathrm{ng} / \mathrm{mL})^{\mathrm{a}}$ & 104.7 & 2602.5 & 5187.3 \\
$\mathrm{SD}$ & 1.42 & 28.10 & 25.57 \\
$\mathrm{RE}(\%)$ & -4.65 & -4.09 & -3.75 \\
$\mathrm{CV}(\%)$ & 1.36 & 1.08 & 0.49
\end{tabular}

7 days at $-20{ }^{\circ} \mathrm{C}$ with 3 freeze-thaw cycles Mean $(\mathrm{ng} / \mathrm{mL})^{\mathrm{a}}$

$\begin{array}{lll}102.5 & 2620.3 & 5030.0\end{array}$

$\mathrm{SD}$

$3.34 \quad 85.17 \quad 41.75$

$\mathrm{RE}(\%)$

$-2.15 \quad-4.83 \quad-0.60$

$\mathrm{CV}(\%)$

$\begin{array}{lll}0.76 & 3.25 & 0.83\end{array}$

7 days at $4{ }^{\circ} \mathrm{C}$

Mean $(\mathrm{ng} / \mathrm{mL})^{\mathrm{a}}$

$\begin{array}{lll}101.6 & 2568.0 & 5025.5\end{array}$

SD

$3.34 \quad 26.71 \quad 186.9$

RE $(\%)$

$\begin{array}{lll}-1.60 & -2.72 & -0.51\end{array}$

$\mathrm{CV}(\%)$

$\begin{array}{lll}3.29 & 1.04 & 3.72\end{array}$

$24 \mathrm{~h}$ at room temperature

Mean $(\mathrm{ng} / \mathrm{mL})^{\mathrm{a}}$

$\begin{array}{lll}103.0 & 2535.8 \quad 4966.5\end{array}$

SD

$\begin{array}{lll}3.75 & 63.12 & 149.5\end{array}$

$\mathrm{RE}(\%)$

$\begin{array}{lll}-2.95 & -1.39 & 0.67\end{array}$

$\mathrm{CV}(\%)$

$\begin{array}{lll}3.64 & 2.49 & 3.01\end{array}$

$60 \mathrm{~min}$ at $56{ }^{\circ} \mathrm{C}$

Mean $(\mathrm{ng} / \mathrm{mL})^{\mathrm{a}}$

$\begin{array}{lll}107.3 & 2431.3 & 5080.0\end{array}$

SD

$\begin{array}{lll}2.96 & 5.59 & 120.4\end{array}$

$\mathrm{RE}(\%)$

$\begin{array}{lll}-7.30 & 2.75 & -1.60\end{array}$

$\mathrm{CV}(\%)$

$\begin{array}{lll}2.76 & 0.23 & 2.37\end{array}$ 
Table 3: Standard laboratory parameters of 6 samples of peritoneal fluid spiked with sorafenib:

\begin{tabular}{|l|c|c|c|c|c|c|c|}
\hline \multirow{2}{*}{} & \multirow{2}{*}{ Unit } & \multicolumn{7}{|c|}{ sample number } \\
\cline { 3 - 8 } & & $\mathbf{1}$ & $\mathbf{2}$ & $\mathbf{3}$ & $\mathbf{4}$ & $\mathbf{5}$ & $\mathbf{6}$ \\
\hline Glucose & $\mathrm{mg} / \mathrm{dL}$ & 235 & 106 & 82 & 106 & 130 & 72 \\
\hline Lactat dehydrogenase & $\mathrm{U} / \mathrm{L}$ & 37 & 396 & 173 & 87 & 35 & 32 \\
\hline Total protein & $\mathrm{g} / \mathrm{dL}$ & 0.8 & 2.4 & 1.8 & 1.6 & 0.5 & 0.9 \\
\hline Albumine & $\mathrm{g} / \mathrm{dL}$ & 0.3 & 1.7 & 1.4 & 0.7 & 0.3 & 0.6 \\
\hline Cholesterin & $\mathrm{mg} / \mathrm{dL}$ & 8 & 31 & 21 & 24 & 5 & 21 \\
\hline Trigyceride & $\mathrm{mg} / \mathrm{dL}$ & 114 & 31 & 20 & 31 & 55 & 85 \\
\hline Weight density & $\mathrm{g} / \mathrm{ml}$ & 1.011 & 1.015 & 1.010 & 1.015 & 1.025 & 1.015 \\
\hline Cell count/leukocytes & $\mathrm{n} \times 1000 / \mu \mathrm{L}$ & 0.2 & 1.1 & 1.6 & 0.7 & 0.0 & 0.0 \\
\hline
\end{tabular}




\section{Figures}

Figure 1: Representative HPLC-chromatograms $(260 \mathrm{~nm})$ of (A) drug-free 5\% BSA sample (blank) and of (B) 5\% BSA sample spiked with $2500 \mathrm{ng} / \mathrm{mL}$ sorafenib (SFB) and the internal standard itraconazole (IS). Retention-times are presented in minutes and amount of absorbance in milli-absorbance-units (mAU).

Figure 2: Calculated and determined sorafenib concentrations detected in spiked peritoneal fluid.

Figure 3: Sorafenib concentrations (in $\mathrm{ng} / \mathrm{mL}$ ) in serum and ascites determined by HPLC. 
[1] Wilhelm SM, Carter C, Tang L, Wilkie D, McNabola A, Rong H, Chen C, Zhang X, Vincent P, McHugh M, Cao Y, Shujath J, Gawlak S, Eveleigh D, Rowley B, Liu L, Adnane L, Lynch M, Auclair D, Taylor I, Gedrich R, Voznesensky A, Riedl B, Post LE, Bollag G, Trail PA (2004) BAY 43-9006 exhibits broad spectrum oral antitumor activity and targets the RAF/MEK/ERK pathway and receptor tyrosine kinases involved in tumor progression and angiogenesis. Cancer Res 64: 7099-109

[2] Keating GM, Santoro A (2009) Sorafenib: a review of its use in advanced hepatocellular carcinoma. Drugs 69: 223-40

[3] Escudier B, Eisen T, Stadler WM, Szczylik C, Oudard S, Staehler M, Negrier S, Chevreau C, Desai AA, Rolland F, Demkow T, Hutson TE, Gore M, Anderson S, Hofilena G, Shan M, Pena C, Lathia C, Bukowski RM (2009) Sorafenib for treatment of renal cell carcinoma: Final efficacy and safety results of the phase III treatment approaches in renal cancer global evaluation trial. J Clin Oncol 27: 3312-8

[4] Kane RC, Farrell AT, Saber H, Tang S, Williams G, Jee JM, Liang C, Booth B, Chidambaram N, Morse D, Sridhara R, Garvey P, Justice R, Pazdur R (2006) Sorafenib for the treatment of advanced renal cell carcinoma. Clin Cancer Res 12: 7271-8

[5] Llovet JM, Ricci S, Mazzaferro V, Hilgard P, Gane E, Blanc JF, de Oliveira AC, Santoro A, Raoul JL, Forner A, Schwartz M, Porta C, Zeuzem S, Bolondi L, Greten TF, Galle PR, Seitz JF, Borbath I, Haussinger D, Giannaris T, Shan M, Moscovici M, Voliotis D, Bruix J (2008) Sorafenib in advanced hepatocellular carcinoma. N Engl J Med 359: 378-90

[6] Benson AB, 3rd, Abrams TA, Ben-Josef E, Bloomston PM, Botha JF, Clary BM, Covey A, Curley SA, D'Angelica MI, Davila R, Ensminger WD, Gibbs JF, Laheru D, Malafa MP, Marrero J, Meranze SG, Mulvihill SJ, Park JO, Posey JA, Sachdev J, Salem R, Sigurdson ER, Sofocleous C, Vauthey JN, Venook AP, Goff LW, Yen Y, Zhu AX (2009) NCCN clinical practice guidelines in oncology: hepatobiliary cancers. J Natl Compr Canc Netw 7: 350-91

[7] Villanueva A, Minguez B, Forner A, Reig M, Llovet JM Hepatocellular carcinoma: novel molecular approaches for diagnosis, prognosis, and therapy. Annu Rev Med 61: 317-28

[8] Llovet JM, Burroughs A, Bruix J (2003) Hepatocellular carcinoma. Lancet 362: 1907-

[9] Liu L, Cao Y, Chen C, Zhang X, McNabola A, Wilkie D, Wilhelm S, Lynch M, Carter C (2006) Sorafenib blocks the RAF/MEK/ERK pathway, inhibits tumor angiogenesis, and induces tumor cell apoptosis in hepatocellular carcinoma model PLC/PRF/5. Cancer Res 66: 11851-8

[10] Strumberg D, Awada A, Hirte H, Clark JW, Seeber S, Piccart P, Hofstra E, Voliotis D, Christensen O, Brueckner A, Schwartz B (2006) Pooled safety analysis of BAY 43-9006 (sorafenib) monotherapy in patients with advanced solid tumours: Is rash associated with treatment outcome? Eur J Cancer 42: 548-56

[11] Coleman J, Wrzosek T, Roman R, Peterson J, McAllister P (2001) Setting system suitability criteria for detectability in high-performance liquid chromatography methods using signal-to-noise ratio statistical tolerance intervals. J Chromatogr A 917: 23-7

[12] Hartmann C, Smeyers-Verbeke J, Massart DL, McDowall RD (1998) Validation of bioanalytical chromatographic methods. J Pharm Biomed Anal 17: 193-218

[13] Jain L, Gardner ER, Venitz J, Dahut W, Figg WD (2008) Development of a rapid and sensitive LC-MS/MS assay for the determination of sorafenib in human plasma. J Pharm Biomed Anal 46: 362-7

[14] Sparidans RW, Vlaming ML, Lagas JS, Schinkel AH, Schellens JH, Beijnen JH (2009) Liquid chromatography-tandem mass spectrometric assay for sorafenib and sorafenib- 
glucuronide in mouse plasma and liver homogenate and identification of the glucuronide metabolite. J Chromatogr B Analyt Technol Biomed Life Sci 877: 269-76

[15] Zhao M, Rudek MA, He P, Hafner FT, Radtke M, Wright JJ, Smith BD, Messersmith WA, Hidalgo M, Baker SD (2007) A rapid and sensitive method for determination of sorafenib in human plasma using a liquid chromatography/tandem mass spectrometry assay. $\mathrm{J}$ Chromatogr B Analyt Technol Biomed Life Sci 846: 1-7

[16] Afify S, Rapp UR, Hogger P (2004) Validation of a liquid chromatography assay for the quantification of the Raf kinase inhibitor BAY 43-9006 in small volumes of mouse serum. J Chromatogr B Analyt Technol Biomed Life Sci 809: 99-103

[17] Blanchet B, Billemont B, Cramard J, Benichou AS, Chhun S, Harcouet L, Ropert S, Dauphin A, Goldwasser F, Tod M (2009) Validation of an HPLC-UV method for sorafenib determination in human plasma and application to cancer patients in routine clinical practice. J Pharm Biomed Anal 49: 1109-14

[18] Clark JW, Eder JP, Ryan D, Lathia C, Lenz HJ (2005) Safety and pharmacokinetics of the dual action Raf kinase and vascular endothelial growth factor receptor inhibitor, BAY 439006, in patients with advanced, refractory solid tumors. Clin Cancer Res 11: 5472-80

[19] Awada A, Hendlisz A, Gil T, Bartholomeus S, Mano M, de Valeriola D, Strumberg D, Brendel E, Haase CG, Schwartz B, Piccart M (2005) Phase I safety and pharmacokinetics of BAY 43-9006 administered for 21 days on/7 days off in patients with advanced, refractory solid tumours. Br J Cancer 92: 1855-61

[20] Furuse J, Ishii H, Nakachi K, Suzuki E, Shimizu S, Nakajima K (2008) Phase I study of sorafenib in Japanese patients with hepatocellular carcinoma. Cancer Sci 99: 159-65

[21] Abou-Alfa GK, Schwartz L, Ricci S, Amadori D, Santoro A, Figer A, De Greve J, Douillard JY, Lathia C, Schwartz B, Taylor I, Moscovici M, Saltz LB (2006) Phase II study of sorafenib in patients with advanced hepatocellular carcinoma. J Clin Oncol 24: 4293-300

[22] Chen K-F, Yu H-C, Liu T-H, Lee S-S, Chen P-J, Cheng A-L Synergistic interactions between sorafenib and bortezomib in hepatocellular carcinoma involve PP2A-dependent Akt inactivation. Journal of Hepatology 52: 88-95

[23] Mross K, Steinbild S, Baas F, Gmehling D, Radtke M, Voliotis D, Brendel E, Christensen O, Unger C (2007) Results from an in vitro and a clinical/pharmacological phase I study with the combination irinotecan and sorafenib. Eur J Cancer 43: 55-63

[24] Piguet AC, Radojevic V, Afthinos M, Hora C, Ledermann M, Saar B, Dufour JF (2009) 536 The combination everolimus (RAD001) plus sorafenib is superior to sorafenib monotherapy in the treatment of hepatocellular carcinoma. Journal of Hepatology 50: S199S199 


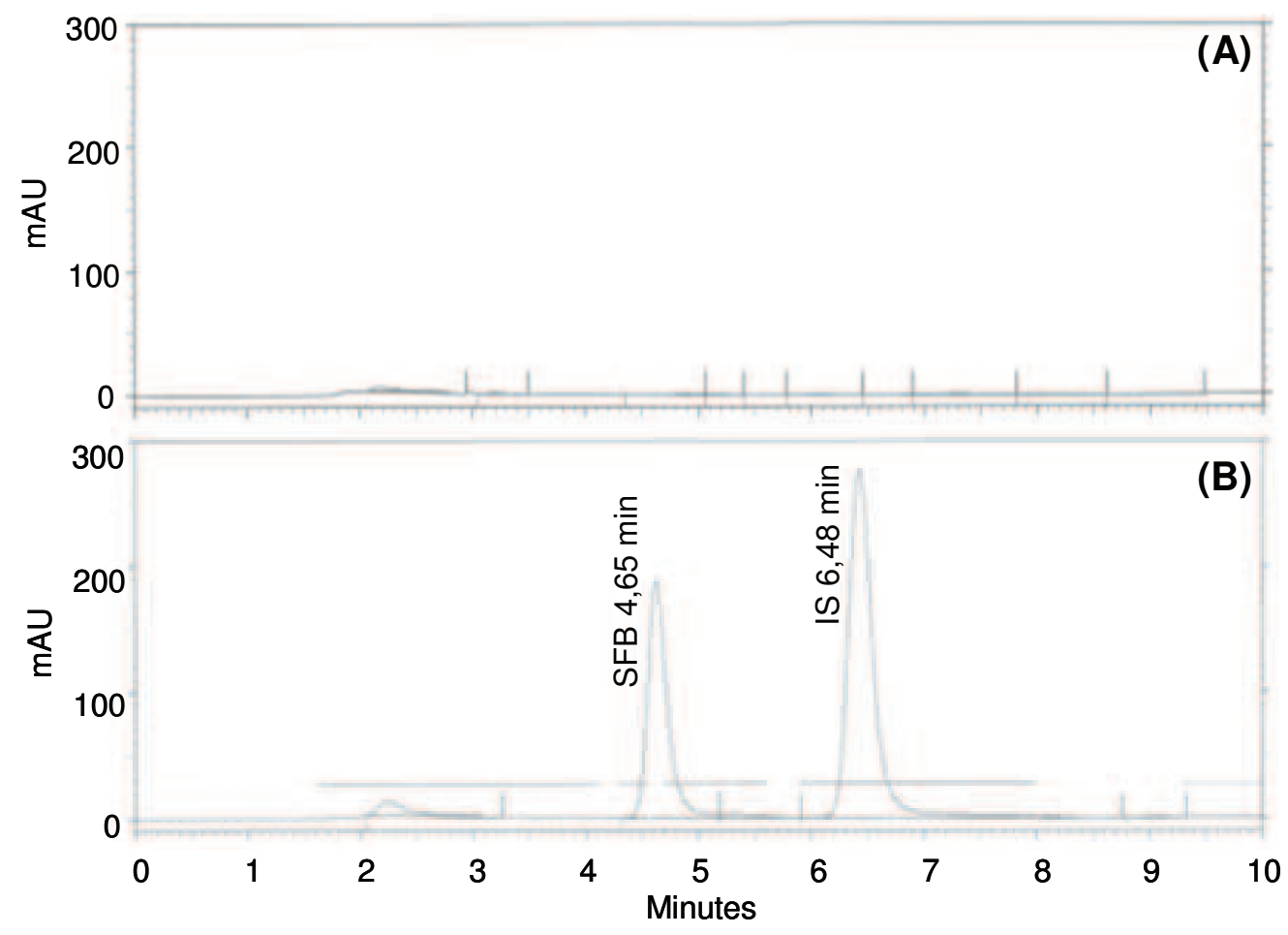




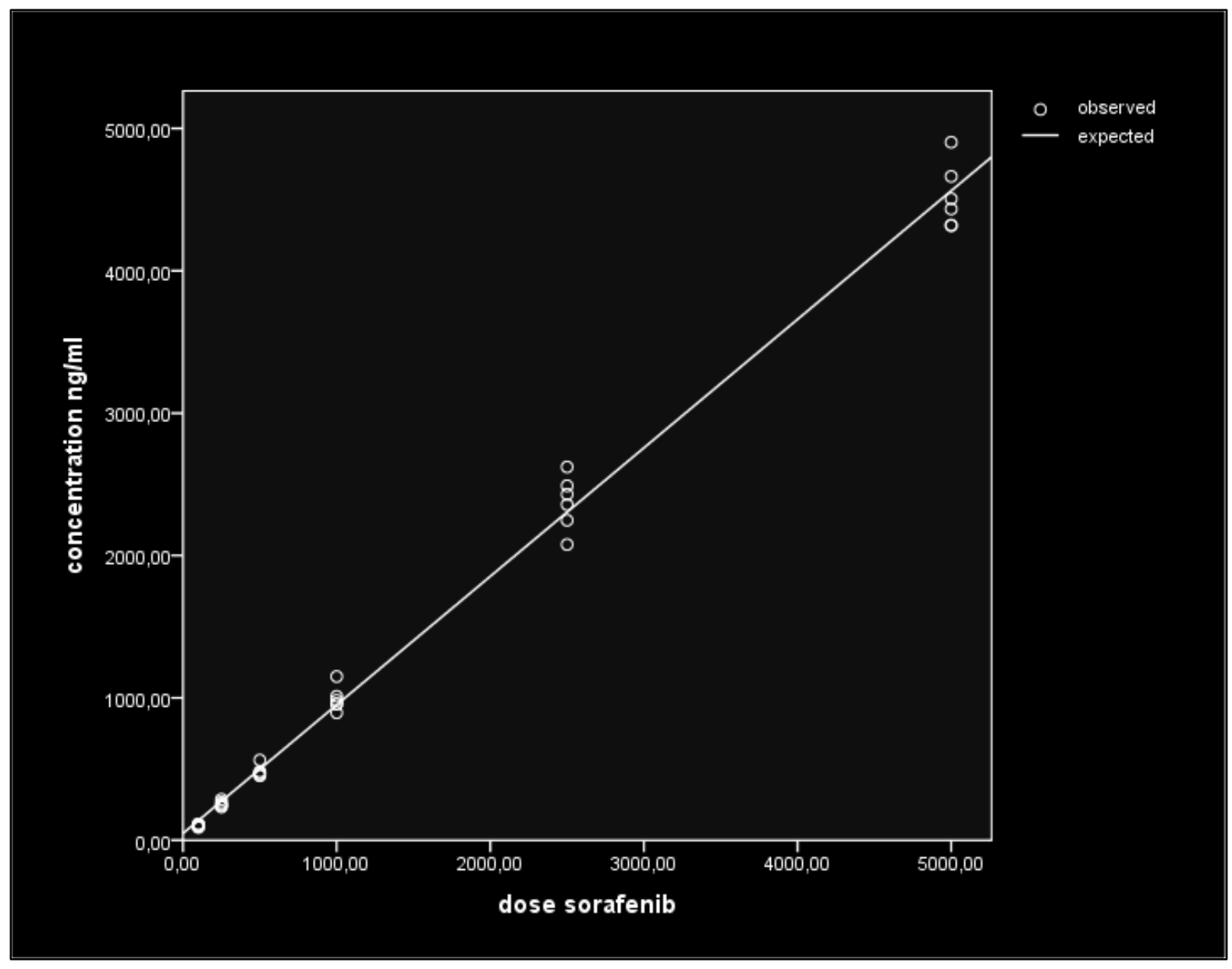




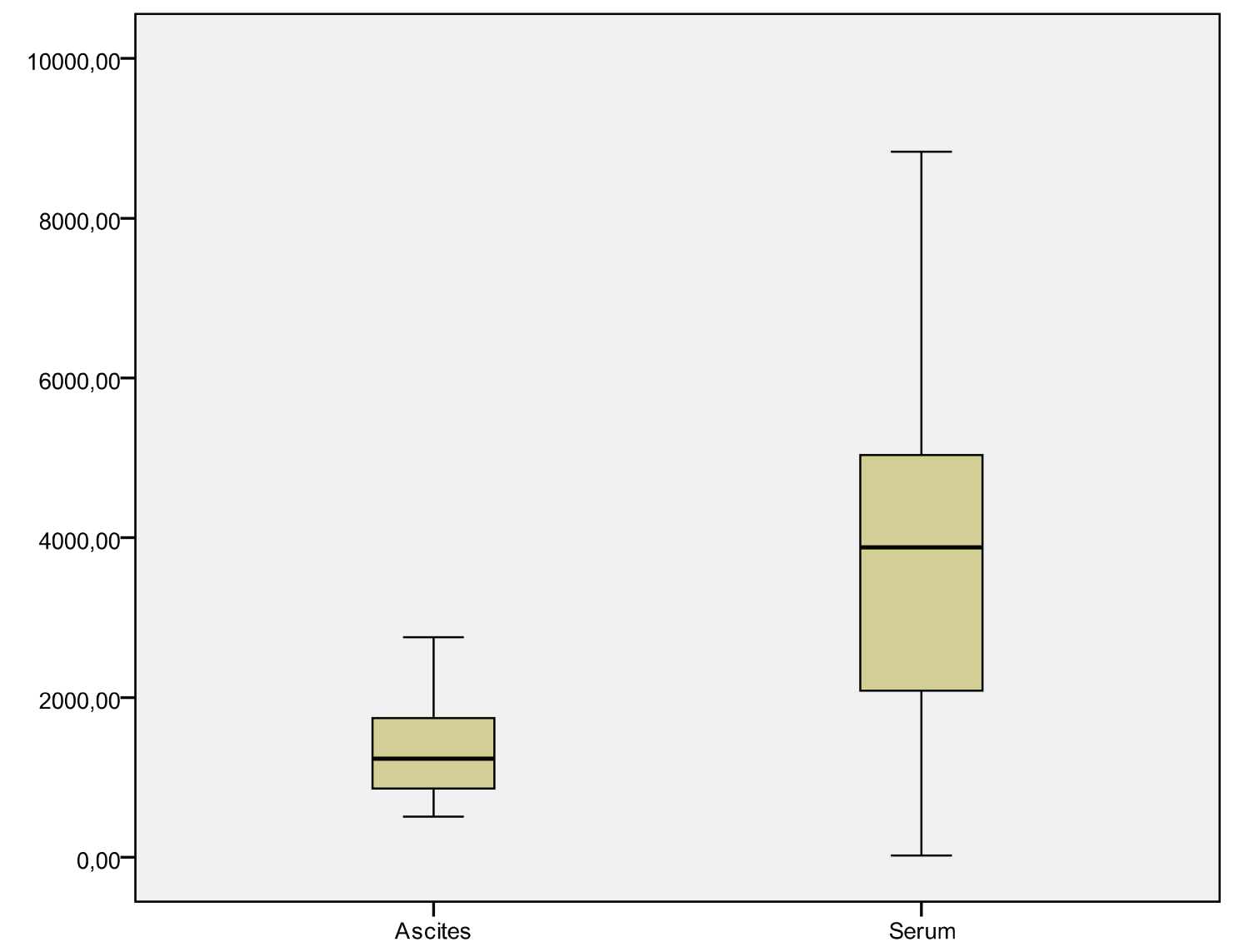

